ish Literature in Foreign Languages. Stockholm: Royal Library, 1963-1976.

Tiblin, Mariann, ed. Scandinavia in English: A Bibliography of Books, Articles, and Book Reviews, 1973-1974. Compiled by Kaaren Grimstad, et al. [s.l.]: Society for the Advancement of Scandinavian Study; Lawrence, Kan.: [Available from]
Allen Press, 1975. Published as Scandinavian Studies, vol. 47, no. 4, supplement.

Tiblin, Mariann, and Susan Larson-Fleming, eds. Scandinavia in English: An Annual Bibliography of Humanities and Social Sciences. Minneapolis: Center for Northwest European Language and Area Studies, 1980.

\title{
French university libraries in 1988
}

\author{
By Joan McConkey \\ Assistant Director for Administration \\ University of Colorado at Boulder Libraries
}

\section{The observations of an American librarian on sabbatical.}

$\mathbf{F}$ or three months I was in France visiting libraries and meeting with French librarians during the winter of 1987-1988. My program was arranged by the international relations office of the Direction des Bibliothèques, de Musées, et de l'Information Scientifique et Technique (DBMIST) of the French Ministry of National Education. It is more usual to go to France as an exchange librarian through a program sponsored by ACRL and the Franco-American Exchange Commission. My position in administrative services does not lend itself easily to exchange, because of the nature of the responsibilities and the rarity of similar positions in French university libraries, so I was pleased to learn that an independent visit to a number of libraries during my sabbatical leave was possible through the same sponsors.

My itinerary included several days at DBMIST for an overview of organization and new developments in French university libraries and visits ranging from one or two days to three weeks in a variety of university libraries. In Paris I also visited the Bibliothèque Nationale and two modern public libraries, the Bibliothèque Publique d'Information (BPI) at the Centre Georges Pompidou and the Médiathèque de la Villette. BPI, a comprehensive public reference library, is very popular with university students who enjoy its free access to materials, special services, and extended hours. The multi-media collection using the latest library technology of the Médiathèque reflects the science and technology emphasis of the City of Science and Industry where it is housed.

The university libraries I saw included the venerable Sorbonne Library and the Bibliothèque Sainte-Genevieve, whose history goes back to a pre-revolutionary abbey library, both in the historic student quarter of Paris; and the modern libraries of the postwar University of Paris X (Nanterre) and the still newer University of Technology of Compiègne. A three-week stay was barely time to absorb the complexity of the Interuniversity $\mathrm{Li}$ brary at Montpellier which serves 40,000 students in three universities with six libraries. In Montpellier I also spent half days in the public library, which has marvelous rare book collections and a very modern media center, and at the departmental archives of Hérault, which are rich in regional history.

A week at the library school in Villeurbanne, a suburb of Lyon, gave me an opportunity to learn about the curriculum, to attend an interesting all- 


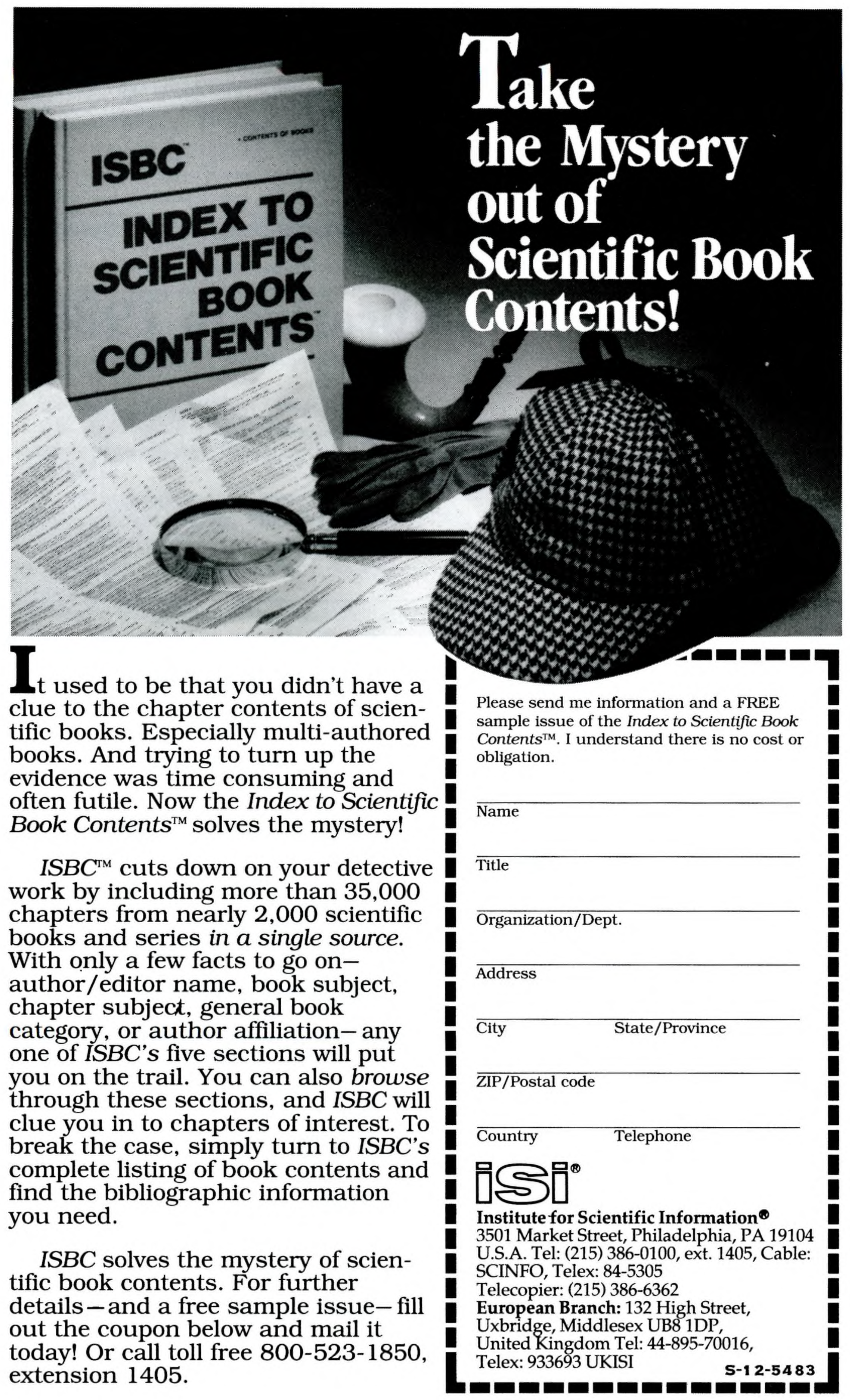


day workshop on the sociology of libraries and librarians, and to visit the attractive sixteen-year-old main library building of the prestigious Lyon public library, two university libraries, and SUNIST, the library computer center.

Basic concerns of U.S. and French university librarians are similar. They include funding levels inadequate to accomplish basic goals, the application of new technologies to library services and management, collection development policies and cooperation among libraries, adequate space for collections and services, greater integration of the library with the university policy-making structure, and the status of librarians.

Approaches to these issues differ because of the highly centralized organizational structure in France and the absence of strong membership organizations like the American Library Association and its divisions and the Association of Research Libraries, which generate new ideas and cooperative schemes in the United States. French university libraries receive their major funding and general direction from DBMIST. It also has the primary responsibility for research and development. Public libraries, including the Bibliothèque Nationale, are administered through the Direction du Livre et de la Lecture of the Ministry of Culture and Communication. This makes cooperative efforts cumbersome, but there are notable achievements such as the National Collective Catalog of Serials (CCN). CCN includes the holdings of 2,600 libraries and documentation centers and serves as an online interlibrary loan service.

\section{Funding and staffing}

The major part of a French university library's budget comes directly from DBMIST rather than from the university. An annual student library fee of less than twenty dollars per student comes from the university. Some libraries receive additional funds from their universities or regional governments and a few market their services to the private sector. The official budget figures do not include salaries. Library staffs, as civil servants, are paid directly by the government. Professional positions are filled by a national committee convened in Paris twice a year by DBMIST. Seniority and keeping civil servant spouses together weigh more heavily than the director's preference and specific qualifications. It has been national policy for several years to cut the number of civil servants; this is particularly difficult for universities with soaring enrollments, static faculty numbers, and declining library staffs. Library staffing cuts (based on comparative statistics) are decided at the ministry level. Individual libraries may be able to supplement civil service staffing with annual contracts, limited hourly work, and a national program for the unemployed, but these provide no continuity. There is no student employment tradition in France because French university education is heavily subsidized by the government and employment is not a necessity for most students.

\section{New technologies}

DBMIST is emphasizing the application of computer technology to library operations in order to improve library services and enhance cooperation among libraries. Probably the most ambitious project is the creation of a "pancatalogue," an online catalog of monographic holdings to complement the National Collective Catalog of Serials. This catalog will use tapes created from several sources. A few university libraries began using OCLC for cataloging this year under the sponsorship of DBMIST and more will be added to this network in the future. Other libraries are using SIBIL (Système Informatisé pour Bibliothèques) developed at the University of Lausanne in Switzerland in the 1970s and first used in France in 1983 at the University of Montpellier. The Bibliothèque Nationale, which would have primary responsibility for subject authority based on the University of Laval's (Canada) translation of Library of Congress subject headings, uses a GEAC system unique to the BN. Many public libraries use the simpler French-developed LIBRA system.

The minitels developed for the French telephone system will provide public access to the pancatalogue in addition to library public access catalogs. There are currently three million minitels in use in France. Minitel access is now provided for the thesis online bibliographical database which includes more than 110,000 titles and adds approximately 16,000 each year. Providing access to theses has been a French priority and each year microfiche copies of all French university theses are provided to each university library.

Computer-based reference service is widely available. The French databases include PASCAL, for science, FRANCIS for the humanities and social sciences, and other more specialized ones. Access is also provided to other European and U.S. sources. There is a charge to users. Englishlanguage encyclopedias and other services on CDROM are available in a few libraries, and French applications of this technology are being tested. An interest in conserving original resources has led to video disk catalogs for preliminary access to special collections.

Automated circulation is provided through SIBIL or a widely used microcomputer system called MOBI-PRET developed by DBMIST. Telefacsimile, electronic mail and audio-conference rooms are available in some libraries.

\section{Collection development policies and cooperation}

Recognition that budget levels do not allow libraries to be self-sufficient in developing research collections has led to a major shared acquisition effort, Centres d'acquisition et de diffusion de l'infor- 
mation scientifique et technique (CADIST). Its purpose is to reinforce already existing national roles for some library subject collections with special funds and acquisition committees. At present there are sixteen broad subject areas, primarily in the sciences, for which selected libraries are receiving funds to buy research materials. National acquisitions committees with a maximum membership of twelve are developing acquisition policies leading to a national conspectus and evaluation methods for each subject area. The CADIST libraries are expected to provide access to these materials through interlibrary loan.

No system like CCN, which provides online and microfiche coverage of serials holdings and incorporates electronic mail for interlibrary loan and other communication, is available for monographs, but the pancatalogue should fulfill this need. The SIBIL libraries have access to each other's cataloging information now. The British Lending Library has online access to CCN and also serves as a source for materials not available in France.

There is strong interest in American collection development and resource sharing programs. The Association of Research Libraries organized training sessions on developing a conspectus. These were presented by French-speaking American librarians and were very well received. Englishlanguage materials are a major part of scientific research collections. Sixty-three percent of the material analyzed in PASCAL, for example, is in English.

\section{Space for collections and services}

French university libraries are usually housed either in aged university buildings which may also contain classrooms, offices, and other university functions, or in characterless modern buildings with similar architectural plans built throughout the country in the early 1970s. The older buildings have closed stacks of necessity since books are often shelved by size and/or chronological order in labyrinthine stacks created wherever space can be found. (The visitor wonders where they will shelve another book in the Sorbonne Library.) Many of the newer buildings have more stacks or stack towers that are also closed to the public, whether or not the books have been classified. Most of these buildings appear to have space to grow, particularly those with modular construction, but space in some has been taken over by outside library agencies or other university functions.

Anyone with experience in adapting a 1930s library for computer applications can at least begin to understand the problems in providing power and electrical conduits in a solidly built 19thcentury structure. The typical overheated, excessively dry environment is as inhospitable to computers as it has been to the collections. Leaking roofs and other maintenance problems with di- vided and unmet responsibilities for upkeep also create problems in utilizing space. These problems are less severe in the 1970s buildings, although one wonders about large skylights admitting the hot sun and torrential rains in the south of France.

The older libraries usually have monumental reading rooms, a catalog room, and a "reserve" for rare books with other service points developed later as best as they can be fitted into a basically inflexible building. The newer libraries were designed for subject area reading rooms and a central circulation area, often creating more service points than staffing levels can cover.

\section{The library in the university structure}

Traditionally the French university library has not been an integral part of the university. This is largely because most of the funding and staff selection are handled at the ministerial level. Indeed, substantial libraries have been created by departments and institutes with little concern about duplication of effort and expense and no provision of professional services. A 1985 decree mandates coordination of resources and a common documentation service. The only place I saw this totally in effect was at the relatively new University of Technology of Compiègne where the library director is a member of the Dean's Council and library materials are centrally purchased, cataloged, and maintained with access provided to the entire university. In other universities there are informal agreements about whether the university library or a departmental library will buy certain types of materials. Progress is being made on the development of a union list of serials and elimination of duplicate subscriptions. A primary role of university libraries has been to provide multiple copies of textbooks and basic reference tools for beginning students. The more sophisticated communication, reference, and resource sharing capabilities of the computer age may hasten the integration of the library into the university.

\section{The status of librarians}

French libraries are hierarchical in organization with fairly rigid steps for librarians within the civil service system. In the past it was customary for library directors to be scholars, as is the historian recently appointed as Director of the Bibliothèque Nationale. Recent appointees are usually graduates of the Ecole Nationale Supérieure de Bibliothécaires (ENSB), the only school in France for librarians (conservateurs), who fill the higher level professional positions. Some students are admitted to the school as civil servants with guaranteed positions upon completion of their studies. Most of them become university librarians. Directors normally have been chosen from the senior Civil Service categories, but in recent years the management skills of lower level conservateurs have been recognized in appointments as directors. Their sal- 
aries remain at their civil service step rather than reflecting the increased responsibility. Heads of sections or departments within a library are usually graduates of ENSB.

Another major category of employees is librarian adjunct. They also have formal library training, but without the educational requirements needed for admission to ENSB. Much of the support for daily operations comes from this group and there is some resentment of the higher salaries and wider opportunities of the conservateurs. There is also a clerical level within the civil service.

Library staffs are counted as bodies rather than FTEs and are small in comparison with those in U.S. libraries. Staffs of more than 100 are rare in French university libraries. Vacation and sick leave policies are generous but sabbatical or research leaves do not exist. There is no opportunity for faculty status. National policies are set by DBMIST with advisory committees made up of directors. Continuing education opportunities for all civil servants are provided by DBMIST with current emphasis on new technologies, communication (work relations and public service), and management. Competitive exams are held for entrance to ENSB as civil servants. Graduates are proud of their achievements and concerned about the lack of public recognition and financial reward.

\section{Summary}

My three-month sojourn in France was an excellent opportunity to observe library operations in another country and to meet a number of colleagues in various libraries. I was struck by the sim- ilar goals and attitudes of U.S. and French librarians while recognizing many operational differences. The number of hours libraries are open in France, for example, is much less, usually between fifty and sixty a week, with only BPI open on Sunday. Access to the collections is more difficult with closed stacks, card catalogs divided by time periods, and fewer circulating books. National attention is focused, however, on resource sharing and improved bibliographic access to collections through computer applications.

I encourage librarians with more time to explore exchange possibilities. Visiting librarians have more possibilities of becoming part of another library's world if they have definite responsibilities and time to become well acquainted with the library and its staff. It was a challenge for me to meet new people constantly and to adjust to their plans and expectations for me.

French librarians, in general, expect foreign visitors to speak French, but a number of them speak or understand English, and are helpful when problems arise. Although there are many cognates in the specialized vocabulary of librarians, there are also numerous confusing "faux amis" (false friends). I was quite lost in a meeting where etiquette was being discussed, for example, until I realized this was a term for barcode labels. There is a French glossary of library terms with an English index published by AFNOR, and a bilingual dictionary of library terms edited by Souad Hubert of BPI with an English edition scheduled for publication in 1988. Both would be useful companions to the English-speaking librarian in France.

\section{Latin American materials to be more accessible}

The National Endowment for the Humanities and the Department of Education have granted six U.S. research libraries funding for a major card catalog conversion project of citations for their Latin American library materials into national bibliographic online databases. The project has been endorsed as an "Official Quincentenary Project" by the Christopher Columbus Quincentenary Jubilee Commission, recognizing "its exceptional contribution to the Quincentenary" in 1992, when this project will be completed.

Stanford University Libraries is coordinating the entire project, and will be joined in this effort by the University of California at Berkeley, the University of Florida, Indiana University at Bloomington, the University of Texas at Austin, and Yale University. Individually each institution has strong collections in the field of Latin American studies; collectively, their joint resources in Latin America are truly distinctive.
During the first two years of the project, information about portions of each institution's collections on Latin America, which presently is available only in local manual library catalogs, will become part of both the RLIN and OCLC databases, which are very widely used both here and abroad. Adding new records and ownership information for these materials to RLIN and OCLC will achieve a broad sharing of information to all users of these networks, as well as more precise access to each item's author, title, and subject classification.

The project will result in 56,000 new records being added to the two databases over the two-year period. An additional 85,000 records already in the databases will be enhanced with symbols to indicate institutional ownership of the items, increasing their availability through interlibrary borrowing.

The resultant records also will be made available to the Organization of American States' Columbus 
Memorial Library, and thereby to all Latin American countries. This constitutes a valuable asset for scholarship throughout Central and South America, where library holdings and access thereto is often uncertain.

Latin America historically has had, and continues to have, a highly fragmented literary structure. Small publishing runs of materials are quite common and limit the availability of material even in their countries of origin. Comprehensive bibliographies of published materials simply do not exist as they do in other areas of the world, and legal mechanisms to ensure that new imprints are reported to, or deposited in, national libraries have functioned fitfully at best. National libraries have been damaged or destroyed in Peru and Nicaragua, making materials outside the country the only extant copies.

The conversion project concentrates on each institution's particular strengths. For example, the University of Florida's Caribbean collection reflects nearly 30 years of concentration on collecting West Indies materials. The University of Texas' Benson Latin American Collection results from a comprehensive collecting policy for over 40 years. The University of California's materials targeted for this project are extremely strong in nineteenthand early twentieth-century titles. Yale has one of the oldest Latin American collections in the entire country. Stanford's initial activity will be in materials from Chile and Colombia.
The project was initiated under the auspices of the Association of Research Libraries' "North American Program for Coordinated Retrospective Conversion" as one of several discipline-centered projects building toward comprehensive bibliographic automation. Latin American studies was selected as a priority area for conversion, as the various weak features of Latin America's book trade and bibliographic infrastructure create an especially clear and urgent need. The Seminar on the Acquisition of Latin American Library Materials (SALALM) is deeply concerned with improved access to Latin Americanist research resources, and has offered its support by appointing two liaisons to the project from the University of North Carolina and UC Berkeley.

Several projects currently underway or completed at the University of California, Los Angeles, Tulane University, and the Bancroft Library at UC Berkeley, encompassing nearly 200,000 records, complement these efforts. In addition, discussions currently are taking place among a number of other academic libraries in addition to the original six participants regarding a third and final year's project. Though the need is substantial, the structures are now in place to achieve a goal which will benefit scholars of Latin America throughout North America and beyond. Six major universities are committed to a success for scholarship by the 500th anniversary of Columbus' landfall in the Western Hemisphere.

\section{ILL librarians in Massachusetts academic libraries are now wired}

An innovative document delivery system linking eleven Massachusetts Public Higher Education Libraries was installed this year. Nine PC-based facsimile and two Group III telefacsimile machines provide for the electronic transmission of periodical articles and other documents to interlibrary loan borrowers. Graphics scanners are used to digitize the material before it is sent.

An integral part of the new system is the Massachusetts State Board of Regents Computer Network, which serves the libraries. Each PC is connected to both the X.25 data communication network and regular telephone lines for outside fax. The fax machines are capable of transmitting both digital and analog signals.

Grant funding for the system was obtained by Ben Franckowiak, director of the University of Lowell Libraries. Other participating institutions are the University of Massachusetts (Worcester, Boston, and Amherst campuses), Southeastern Massachusetts University, Bridgewater State College, Fitchburg State College, Framingham State
College, Salem State College, Mt. Wachusett Community College, and Berkshire Community College. Other public academic libraries in Massachusetts will join the system in the future.

\section{BI resource database}

The ALA Library Instruction Round Table (LIRT) is updating their list of bibliographic instruction programs and resource people for librarians to use as a networking tool. This information will be available through the Library Orientation and Instruction Exchange (LOEX). If you would like to be considered for inclusion in the database or know others who should be included, contact: Eileen Liebeskind, NOTIS Systems, Inc., 1007 Church St., 2d Floor, Evanston, IL 60201; (312) 866-0150. 


\section{Before you spend another dollar on reference works or professional literature...}

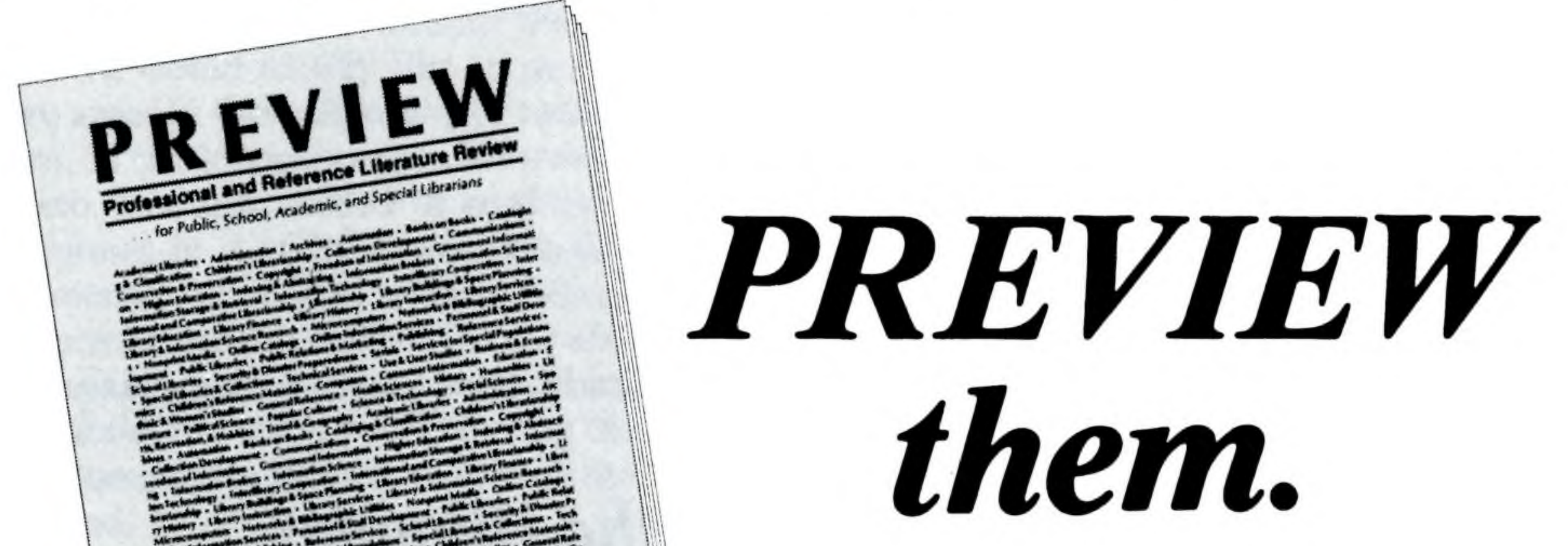

If you're like most librarians, you probably wish you had more time to research the new publications you buy. Particularly since the quantity and cost of those publications are increasing all the time.

Obviously, we can't give you more time. But what we can give you is a buying guide that will allow you to evaluate more publications in less time.

Every issue of Preview contains:

- Summaries of reviews, collected from as many as 100 professional journals, covering both reference works and library literature.

- Original reviews of new reference tools, written by librarians and subject specialists, focusing on recent publications from small presses, professional associations, and other often overlooked sources.

- Notice and evaluation of new publications in library and information science and allied fields.

Special features to keep you up to date. In addition, in each monthly issue of Preview you'll find the following special sections:

- Software for Library Applications

- New Editions (of standard reference works)

- Children's Reference Materials

- News \& Views

\section{A suggestion: Don't buy another publi-} cation until you've PREVIEWed it.

Act now for a special offer. Receive 11 monthly issues at a charter subscription price of just \$35that's a savings of $\$ 8$ off the regular annual subscription rate of $\$ 43$. And, when you subscribe now, you'll also receive five of our handy Reference Book Guides-at no additional cost!

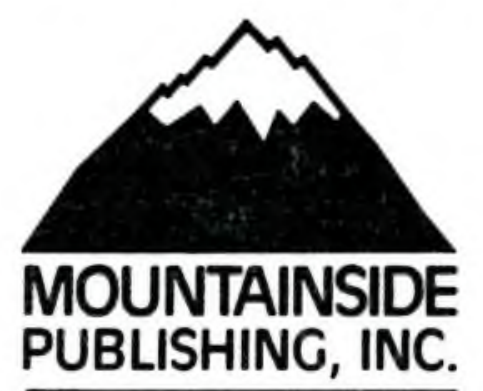

YES, I'd like a charter subscription to Preview.

Name

Address

City

State Zip

Check enclosed. $\quad \square$ Please bill me.

Please send a free sample issue.

Mail this completed form to:

Mountainside Publishing, Inc.

P.O. Box 8330 • Ann Arbor, MI 48107

(313) 662-3925 